\title{
Effect of age and sex on meat quality and quantity of Black Bengal goat
}

\author{
S Mehjabin ${ }^{1}$, MR Amin $^{1 *}$, MO Faruque ${ }^{2}$, MB Sarker $^{1}$ \\ ${ }^{1}$ Department of Animal Science, Bangladesh Agricultural University, Mymensingh; ${ }^{2}$ Department of Animal \\ Breeding and Genetics, Bangladesh Agricultural University, Mymensingh, Bangladesh
}

\begin{abstract}
The present research was conducted to investigate the effect of sex and age of goats on live weight, hot carcass weight, dressing percentage, chemical composition and $\mathrm{pH}$ of meat obtained from Black Bengal goat. Fifty goats of different age (up to 3 years) and sex groups (buck, castrated male, doe and kids) were slaughtered. After pre-slaughter weighing goats were sacrificed using the approved "Halal" method. The average live weight of doe up to one, two and three years of age were 12.51, 14.35 and $16.35 \mathrm{~kg}$ and of buck were 10.57, 19.29 and $37.05 \mathrm{~kg}$, respectively. There were significant differences between the live weight of doe and buck at different age group. Hot carcass weight of doe and buck differ significantly among the different age group also differ significantly between the different sex group's goat. The mean hot carcass weight of castrated male at one year of age was $7.82 \mathrm{~kg}$ and was observed highest in castrated male than doe and buck. The average dressing percentage of doe, buck and castrated male at one year of age was $42.02,39.01$ and $43.56 \%$, respectively but the values did not differ significantly. There were no significant differences of DM, moisture and CP content between doe and buck at different age group but significant differences were observed among the different age group of doe and buck. Fat content was significantly different among the different age group of doe and buck. There was significant difference of ash among the different age group of doe and buck. The $\mathrm{pH}$ values of goat meat did not differ significantly among the different age and sex of goats. From this study, it was concluded that the meat quantity in terms of hot carcass weight and dressing percentage were higher when castrated male slaughter within one year whereas maximum hot carcass weight was obtained when buck slaughter at the age 2-3 years and meat quality in terms of crude protein content was higher in meat obtained from buck and ether extract content was lower in buck meat when slaughter within one year.
\end{abstract}

Key words: Black Bengal goat, Buck, Castrated male, Doe, Meat quality.

Bangladesh Animal Husbandry Association. All rights reserved.

Bang. J. Anim. Sci. 2016. 45 (1): 19-24

\section{Introduction}

In Bangladesh, goat rearing is a potential means for poverty eradication, supplying nutrition and creating job opportunities. Goats play a crucial role in the subsistence economy of smallholder farmers in Bangladesh. Goats, the most popular small ruminant animals, are found throughout the country and are potential resource for supplying high quality meat and skin. They are also considered a potential animal genetic resource for poverty alleviation as they are the source of income for many small and landless farmers. They stand second in number among the ruminant species. The contribution of the livestock sub-sector to gross domestic products (GDP) during FY 2011-12, from this sub-sector

*Corresponding Author: aminmr64@yahoo.com was 2.50 percent (DLS, 2012). Though the share of the livestock sub-sector in GDP is small, it has immense contribution towards meeting the daily protein (animal protein) requirements. Among the 52.836 millions ruminant livestock (cattle, buffalo, goat and sheep) population goat comprises 25.116 million (2011-12) which is about $47.54 \%$ of total livestock population and represent the highest population in Bangladesh (DLS, 2012). The growth rate of goat population is $3.85 \%(2011-12)$. Black Bengal goat comprises more than $90 \%$ of the total goat population and kept by the rural people in Bangladesh. The goat ranks second in position in terms of meat, milk, and skin production, representing about 28, 23, and 28 percent, respectively of the total livestock in Bangladesh. The per capita daily meat requirement is $120 \mathrm{~g}$ 
but the per capita daily availability is $22.0 \mathrm{~g}$ (DLS, 2010). People of Bangladesh get less than one fifth animal proteins of the required recommendation (Chawdhuri et al., 1993). Goat and sheep produced 4.9 and 8.6 million tons meat respectively (FAO, 2008). Around 15 million goats and 5 million sheep are slaughtered annually, mostly of which are local origin. Of the total slaughtered cattle and goats, around 40 percent is slaughter during Eid-ul-Azha (BER, 2010).

The country has a native goat breed commonly known as the Black Bengal goat. Black Bengal goats are dwarf meat type goats usually distributed in Bangladesh and its surrounding areas in India. They are popular for their adaptability in hot and humid environment, high prolificacy, delicious meat and skin softness. Black Bengal goats are found all over the country. They can be classified into 3 sub populations as Bangladesh West (BBW), Bangladesh Central (BBC) and Bangladesh East (BBE) according to their geographical distribution. However, Black Bengal goats are clearly predominant (Faruque, 2009).

The phenotypes of Black Bengal goats in the central region of Bangladesh (BBC) have been investigated by Hussain et al., (1998), Jalil (2003), Abedin et al., (2005), Assaduzzaman et al., (2009) and Khandoker (2011) but few study have been done on quality and quantity of Black Bengal goats meat. Therefore, the present study was designed to investigate the effect of sex and age on live weight, hot carcass weight, dressing percentage, chemical composition and $\mathrm{pH}$ of meat obtained from Black Bengal goat.

\section{Materials and Methods \\ Experimental animal}

The experimental Black Bengal goats were reared under semi-intensive systems in the village of Nagar of Baraigram Upazilla and in the village of Khamar Pathuria of Gurudaspur Upazilla in Natore district. Fifty (50) goats of different age (between 3 months to 3 years) and sex groups (buck, castrated male, doe and kids) were slaughtered. The bucks, castrated males, does and kids were reared under semi intensive management system commonly practiced by the farmers all over the country. The does along with the kids and bucks were allowed to graze in naturally available pasture land around the village during the day time. At night time, they were kept confinement in the goat shed or other places suitable for the farmers. In some occasion, the does were tethered by rope and allowed to graze by road side or suitable pasture land convenient for the farmers. Trees leaves viz., mango leaves, jack fruit leaves, banana leaves or grasses from the cultivated land were fed during the rainy season. Goats were fasted overnight before slaughter. After pre-slaughter weighing goats were sacrificed using the approved "Halal" method. By this method, goats were bled by cutting throat and then slaughtered by severing the head at its articulation on the occipito-atlantal space. After complete bleeding, the slaughtered animals were skinned.

Carcass and non carcass components (head, skin, feet, digestive tract, liver, spleen, pancreas and pluck) were weighed immediately after slaughtering. Lungs, trachea and heart were weighed separately and designated as pluck.

\section{Live weight}

Live weight of each goat was taken before slaughter using a digital balance.

\section{Hot carcass weight}

Weight of the carcass was taken with the help of weighing balance within one hour of slaughtering.

\section{Dressing percentage}

Dressing percentage (DP) was calculated on the basis of hot carcass weight. Dressing percentage was calculated as follows: $D P=$ (Hot carcass weight/Live weight) $\times 100$

\section{Chemical analysis}

Meat was taken from five different locations (i.e. neck, fore quarter, hind quarter, back, \& flank) of the carcass and chopped to small pieces. The pieces were mixed thoroughly and finally the samples (200 g per goat) were collected to determine chemical composition of meat by proximate analysis (AOAC, 1984).

\section{pH}

The $\mathrm{pH}$ value of meat was measured using $\mathrm{pH}$ meter (corning) from meat homogenate. The homogenate was prepared by blending $2 \mathrm{~g}$ of meat with $10 \mathrm{ml}$ of chilled distilled water. 


\section{Statistical analysis}

The data generated from this experiment were analyzed with the help of SPSS (Statistical package for social science, Release August 23, 2008). All data were subjected to one-way ANOVA and were represented as the mean \pm SE (standard error).

\section{Results and Discussion}

\section{Live weight of goat}

Table 1 shows that live weight of Black Bengal goat in different age and sex group. There was a significant difference between the live weight of doe and buck at different age group. The highest live weight was obtained in buck at 2-3 years of age (Table 1 ). The mean live weight of castrated male at 0-1 year age group was $13.8 \mathrm{~kg}$ and found highest in castrated male than doe and buck within the same age group (Table 1 ).

Live weights of buck within same age group were significantly higher than the doe only exception was observed in the 0-1 year age group. Asaduzzaman (2008) found the live weight of Black Bengal goat was $12.6 \pm 0.89 \mathrm{~kg}$ which is also lower than the present findings. The live weight of Black Bengal goat was $5-20 \mathrm{~kg}$ found by Singh et al. (1983). The present findings were within the range of Singh et al. (1983). This higher value in the present findings may be due to the effect of age, feed, management, regional variation and genetic makeup of goat.

Table 1. Live weight and hot carcass weight $(\mathrm{kg})$ of Doe and Buck at different age group (mean $\pm \mathrm{SE}$ )

\begin{tabular}{|c|c|c|c|c|c|}
\hline \multirow{2}{*}{$\begin{array}{c}\text { Variates } \\
(\mathbf{k g})\end{array}$} & \multirow{2}{*}{ Sex } & \multicolumn{3}{|c|}{ Age } & \multirow{2}{*}{ Significance } \\
\hline & & 0-1 year & 1-2 years & 2-3 years & \\
\hline \multirow{4}{*}{ Live weight } & Doe & $12.51 \pm 1.69$ & $14.35 \pm 1.20$ & $16.35 \pm 7.35$ & $* *$ \\
\hline & Buck & $10.57 \pm 2.92$ & $19.29 \pm 1.30$ & $37.5 \pm 1.50$ & \\
\hline & Castrated male & $13.80 \pm 2.35$ & & & \\
\hline & Level of Significance & $* *$ & $* *$ & $* *$ & \\
\hline \multirow{4}{*}{$\begin{array}{l}\text { Hot Carcass } \\
\text { weight }\end{array}$} & Doe & $6.21 \pm 0.46$ & $7.6 \pm 0.59$ & $8.05 \pm 0.05$ & $*$ \\
\hline & Buck & $4.64 \pm 1.68$ & $10.27 \pm 1.96$ & $20.85 \pm 4.35$ & * \\
\hline & Castrated male & $7.82 \pm 0.76$ & & & \\
\hline & Level of Significance & $*$ & $*$ & $*$ & \\
\hline
\end{tabular}

* Significant at $5 \%$ level, ${ }^{* *}$ Significant at $1 \%$ level.

\section{Hot carcass weight of goat}

The hot carcass weight of Black Bengal goat in different age and sex group shows in Table 1 . There were significant differences between the hot carcass weight of doe and buck at different age group and highest hot carcass weight was observed in buck at 2-3 years of age. The mean hot carcass weight of castrated male at one year of age was $7.82 \mathrm{~kg}$ and was observed highest among the same age group (Table 1). Asaduzzaman (2008) found the hot carcass weight was $5.93 \pm 0.46 \mathrm{~kg}$ which is also lower than the present findings.

This higher value in the present findings may be due to the effect of age, management, regional variation and genetic makeup of goat.
Dressing percentage of Doe, Buck and Castrated male at (0-1) year age group

The dressing percentage of Black Bengal goat in different age and sex group shows in Table 2 . The dressing percentage did not differ significantly among the different sex group of goat but the highest dressing percentage was observed in castrated male which indicate that castrated male goat have higher muscle deposition capacity than others (Table 2). In the present study, average dressing percentage of Black Bengal goats is consistent with the values observed by Abedin (2005); Das et al. (2001) and Moniruzzaman et al. (2002) but higher than the value (36.61) of Singh et al. (1985). On the other hand, the dressing percentage of Black Bengal goat was reported to be higher ( $46.4 \%$ ) by Chowdhury and 
Faruque (2004) than the value (Table 2) obtained from the present study.

Table 2. Dressing percentage of goats (mean \pm SE)

\begin{tabular}{llr}
\hline Variate (\%) & Sex & Age (0-1 year) \\
\hline \multirow{2}{*}{ Dressing } & Doe & $42.02 \pm 1.43^{\mathrm{a}}$ \\
percentage & Buck & $39.01 \pm 3.29^{\mathrm{a}}$ \\
& Castrated male & $43.56 \pm 3.51^{\mathrm{a}}$
\end{tabular}

*Dressing percentages (calculated as hot carcass weight / live weight) $x$ 100), Similar superscript letter indicate non significant differences.

\section{Dry matter}

The chemical composition and $\mathrm{pH}$ of meat obtained from Black Bengal goat shows in the Table 3. There was no significant difference of DM content of meat obtained from doe and buck among the same age group but significant difference were observed among the different age groups of doe and buck (Table 3). The DM content was increased gradually with the increased age of the doe and buck.

Pearson and Duatson (1999) reported that the average DM percent of meat increase as the animals mature this result is consistent with the present study. Islam (2007) found the DM content of the goat carcass of 1,2 and 3 years of age was $26.69,30.79$ and $30.35 \%$ respectively, which is higher than the present findings. Abedin (2005) and Monizrumman et al. (2002) found the DM content of Black Bengal goat meat was 25.63 and $26.80 \%$, respectively which is almost similar to the present finding. Chowdhury and Faruque (2004) reported the DM content of hind leg region of Black Bengal goat was $28.68 \%$ which was higher than the present result.

\section{Crude protein}

There were no significant differences in Crude protein (CP) content of meat obtained from goats among the doe and buck within the same age group but CP content differ significantly among the different age group (Table 3 ). As the animals become mature CP content significantly decline.

Abedin (2005) found CP content of Black Bengal goat meat was $20.52 \pm 1.02$, which was slightly lower than the present study. Asaduzzaman (2008) found the CP content of Black Bengal goat meat was $21.9 \pm 0.63$ which is almost similar with the present finding. Chowdhury and Faruque (2004) mentioned the CP content of Black Bengal goat meat was $58.64 \%$ on dry matter basis, which is similar to the present result. Islam (2007) found the CP content in meat of 1,2 and 3 years of age goat was 24.982, 24.127 and $23.918 \%$, respectively, which is higher than the present result.

\section{Ether Extract}

Ether Extract (EE) content of meat obtained from the same age group did not differ significantly between doe and buck but there was significant difference of EE content between doe and buck at different age group. As the age of goat increase the EE content of meat also increased which indicate the deposition of fat in meat.

Islam (2007) found the fat content in the goat carcass of 1,2 and 3 years aged was $7.47,7.80$ and $8.22 \%$, respectively which is higher than the present findings. Abedin (2005) found the EE content of Black Bengal goat meat was $3.29 \pm$ $0.57 \%$, which was higher than the present study. Chowdhury and Faruque (2004) found the EE content in meat of Black Bengal goat was $4.90 \%$ on fresh basis, which was also higher than that of the present study. Asaduzzaman (2008) found the EE content of Black Bengal goat was $3.72 \pm$ 0.54 , which was also higher than finding obtained from the present study.

\section{Ash}

Ash percentage of goat meat obtained from doe and buck differ significantly among the different age groups. Ash content of meat obtained from the 1-2 years aged group did not differ significantly between doe and buck (Table 3 ). Abedin (2005) found the ash content of the carcass of Black Bengal goat was $1.23 \%$, which is almost similar to the present study. The ash content of carcass of Black Bengal goat in the present study is higher than the finding of Moniruzzaman et al. (2002) but similar (1.15\%) to the present findings reported by Asaduzzaman (2008). 
Table 3. Chemical composition and pH of goat meat at different ages (mean $\pm \mathrm{SE}$ )

\begin{tabular}{|c|c|c|c|c|c|}
\hline \multirow{2}{*}{$\begin{array}{c}\text { Variates } \\
(\%)\end{array}$} & \multirow[b]{2}{*}{ Sex } & \multicolumn{3}{|c|}{ Age } & \multirow{2}{*}{$\begin{array}{l}\text { Level of } \\
\text { Significa } \\
\text { nce }\end{array}$} \\
\hline & & 0-1 year & 1-2 year & 2-3 year & \\
\hline Dry Matter & $\begin{array}{l}\text { Doe } \\
\text { Buck } \\
\text { Level of Significance }\end{array}$ & $\begin{array}{l}24.96 \pm 0.14 \\
25.20 \pm 0.15 \\
\text { NS }\end{array}$ & $\begin{array}{l}25.14 \pm 0.23 \\
25.31 \pm 0.33 \\
\text { NS }\end{array}$ & $\begin{array}{l}26.95 \pm 0.05 \\
26.58 \pm 0.93 \\
\text { NS }\end{array}$ & $\begin{array}{l}* \\
*\end{array}$ \\
\hline Crude Protein & $\begin{array}{l}\text { Doe } \\
\text { Buck } \\
\text { Level of Significance }\end{array}$ & $\begin{array}{l}22.60 \pm 0.13 \\
22.76 \pm 0.21 \\
\text { NS }\end{array}$ & $\begin{array}{l}21.97 \pm 0.61 \\
21.01 \pm 0.52 \\
\text { NS }\end{array}$ & $\begin{array}{l}19.98 \pm 0.08 \\
20.55 \pm 1.20 \\
\text { NS }\end{array}$ & $\begin{array}{l}* \\
*\end{array}$ \\
\hline Ether Extract & $\begin{array}{l}\text { Doe } \\
\text { Buck } \\
\text { Level of Significance }\end{array}$ & $\begin{array}{l}1.20 \pm 0.08 \\
1.52 \pm 0.12 \\
\text { NS }\end{array}$ & $\begin{array}{l}2.69 \pm 0.20 \\
2.83 \pm 0.23 \\
\text { NS }\end{array}$ & $\begin{array}{l}3.05 \pm 0.05 \\
3.96 \pm 0.25 \\
\text { NS }\end{array}$ & $\begin{array}{l}* * \\
* *\end{array}$ \\
\hline Ash & $\begin{array}{l}\text { Doe } \\
\text { Buck } \\
\text { Level of Significance }\end{array}$ & $\begin{array}{l}1.11 \pm 0.08 \\
1.10 \pm 0.03 \\
\text { NS }\end{array}$ & $\begin{array}{l}1.41 \pm 0.21 \\
1.51 \pm 0.15 \\
*\end{array}$ & $\begin{array}{l}1.55 \pm 0.03 \\
1.63 \pm 0.53 \\
*\end{array}$ & $\begin{array}{l}* \\
*\end{array}$ \\
\hline $\mathrm{pH}$ & $\begin{array}{l}\text { Doe } \\
\text { Buck } \\
\text { Level of Significance }\end{array}$ & $\begin{array}{l}5.33 \pm 0.32 \\
5.63 \pm 0.04 \\
\text { NS }\end{array}$ & $\begin{array}{l}5.51 \pm 0.03 \\
5.54 \pm 0.10 \\
\text { NS }\end{array}$ & $\begin{array}{l}5.22 \pm 0.02 \\
5.27 \pm 0.01 \\
\text { NS }\end{array}$ & $\begin{array}{l}\text { NS } \\
\text { NS }\end{array}$ \\
\hline
\end{tabular}

* Significant at $5 \%$ level, ** Significant at $1 \%$ level, NS = Non-significant

However, Islam (2007) found the ash content of 1,2 and 3 years aged goat were $0.98,0.919$ and $0.911 \%$, respectively, which is slightly lower than the present result.

\section{pH}

There were no significant differences among the three age group animal in $\mathrm{pH}$ content of meat. The $\mathrm{P}^{\mathrm{H}}$ value of Black Bengal goat meat obtained from the same age group did not differ significantly between doe and buck (Table 3 ). The $\mathrm{P}^{\mathrm{H}}$ value of the present study is consistent with findings reported by Tirupal and Ereenivas (1998).

\section{Summary and Conclusions}

The present research was conducted to investigate the effect of sex and three age group goats on live weight, hot carcass weight, dressing percentage, chemical composition and $\mathrm{pH}$ of meat obtained from Black Bengal goat of Bangladesh. The mean live weight of castrated male at one year of age was $13.80 \mathrm{~kg}$ and was found highest in castrated male than doe and buck. However, there was a significant difference between the hot carcass weight of doe and buck at different age group. The mean hot carcass weight of castrated male was found highest among them. The dressing percentage had no significant differences among the different age group of goats. There were no significant differences of DM and CP content between doe and buck at different age group but significant differences were observed among the different age group of doe and buck. EE content was significantly different between and among the different age group of doe and buck. There was significant difference of ash among the different age group of doe and buck.

From this study, it was concluded that the meat quantity in terms of hot carcass weight and dressing percentage were higher when castrated male slaughter within one year whereas maximum hot carcass weight was obtained when buck slaughter at the age 2-3 years and meat quality in terms of crude protein content was higher in meat obtained from buck and ether extract content was lower in buck meat when slaughter within one year.

\section{References}

Abedin, SMA 2005: A study on meat quality and quantity of ruminant species in Bangladesh. M. S. Thesis. Department of Animal Breeding and Genetics, Bangladesh Agricultural University, Mymensingh, Bangladesh. 
Abedin, SMA; Alam, MR; Faruque, MO 2005: Comparative carcass characteristics of ruminant species. Journal of Bangladesh Agricultural University 3 243-248.

AOAC, 1984. Official methods of analysis (14 ${ }^{\text {th }}$ edition), Association of Official Analytical Chemists, Washington, DC, USA.

Asaduzzaman, M; Alam, MR; Faruque, MO 2009: Comparative study on carcass characteristics between Black Bengal and crossbred goats. Journal of Bangladesh Agricultural University. 7 87-90.

Asaduzzaman, M 2008: Evaluation of the carcass yield and meat quality of Black Bengal and Crossbred goats in Bangladesh. M.S. Thesis. Department of Animal Breeding and Genetics, Bangladesh Agricultural University, Mymensingh.

BER, 2010: Bangladesh Economic Review, A Report for Livestock Perspective Plan.

Chawdhury, SD; Latif, MA; Debnath, SC 1993: Appropriate level of education for trainers in backyard poultry raisers training program as determined by their performance. International Journal of Animal Science. 17 848-856.

Chowdhury, SA; Faruque, S 2004: Meat production characteristics of Black Bengal goat. Asian-Australian Journal of Animal Science. 17 848-856.

Das, S; Hussain, SS; Hoque, MA; Amun, MR 2001: Association between boey measurement and carcass traits of goats. Bangladesh Journal of Animal Science. 30 85-91.

DLS (Department of Livestock Service) 2012: Development and work plan, Ministry of Livestock and Fisheries, Government of Peoples' Republic of Bangladesh, Dhaka.

DLS (Department of Livestock Service) 2010: Development and work plan, Ministry of Livestock and Fisheries, Government of Peoples' Republic of Bangladesh, Dhaka.

FAO, 2008: Prod STAT livestock primary and processed write University, Food and Agriculture Organization of the United Nations.http://faostat.fao.org/site/569/Deskt opDefault.aspx. pageID $=569$.

Faruque, MO 2009: Final report of research project entitled "Gene based technologies in livestock breeding": Phase 1Characterization of small Ruminant Genetic Resource in Asia. International Livestock Research Institute. Vienna. 37.

Hussain, SS; Amin, MR; Islam, ABMM 1998: Goat Production and its Breeding Strategy in Bangladesh. Proceedings of the $1^{\text {st }}$ National Workshop on Animal Breeding. 26, November. Bangladesh Agricultural University, Mymensingh, Bangladesh. 17-36.

Islam, R 2007: Quality determination of different wholesale cuts of goat carcass at different ages. M. S. thesis. Department of Animal Science, Bangladesh Agricultural University, Mymensingh.

Jalil, MA 2003: Characterization and conservation of Black Bengal goat. Proc. Annual Research Review Workshop, Bangladesh Livestock Research Institute. 20-25.

Khandoker, MAMY 2011: Conservation of Black Bengal goat as the potential genetic resource in Bangladesh. Proceedings of the conference on popularization of Black Bengal goat farming: need policy intervention, people's participation, and promotion held in Bangladesh Agricultural University, Mymensingh, 16 April, 2011.

Moniruzzaman, M; Hashen, MA; Akther, S; Hossain, MM 2002: Effect on different feeding system on carcass and non- carcass parameters of Black Bengal goats. AsianAustralian Journal of Animal Science. 15 6165.

Pearsons Gillett, AM; Duatson, TR 1999: Meat and Health.Amsterdam: Elsevier Science Publishers.

Singh, CSP; Singh, DK; Singh, R; Nath, S; Mishra, HR 1983: Some carcass characteristics of Black Bengal and crossbred goats. Indian Journal of Animal Science. 53 560-561.

SPSS, Statistics 17.0 (Release Aug 23, 2008): This product uses WinWrap Basic, Copyright 1993-2007, Polar Engineering and Consulting, http://www.winwrap.com. http://www.spss.com.

Tirupal, RN; Ereenivas, RM 1998: The effect of postmortem ageing temperature on certain quality characteristics of mutton. Indian Journal of Animal Science. 681295. 